\title{
Amphipod Paramphithoe hystrix: a micropredator on the sponge Haliclona ventilabrum
}

\author{
P. E. Oshel \& D. H. Steele \\ Biology Department, Memorial University, St. John's, Newfoundland A1B 3X9, Canada
}

\begin{abstract}
The amphipod crustacean Paramphithoe hystrix is shown by SEM gut-content analysis to eat the tissue of its sponge host Haliclona ventilabrum and to swallow the sponge's siliceous spicules whole. Mandibular molar processes are modified to manipulate the spicules without breakage. The upper lip has pores, possibly mucus-gland ducts, from which mucus secretion appears to coat the spicules prior to swallowing thus preventing injury.
\end{abstract}

Associations between amphipods and invertebrates, including sponges, have been reported frequently (Arndt 1933, Vader 1978, 1983), those between invertebrates and paramphithoid amphipods less often. Vader (1978) reported Epimeria parasitica on holothurians and asteriods, and Paramphithoe hystrix was recorded on the sponge Cladocroce ventilabrum ${ }^{*}$ by Fenwick \& Steele (1983). The latter was the first report of a paramphithoid amphipod associated with a sponge.

Paramphithoe hystrix were collected from the sponge Haliclona ventilabrum at ca $35 \mathrm{~m}$ depth by SCUBA diving in Bonne Bay, Newfoundland $\left(49^{\circ} 30^{\prime} \mathrm{N}, 57^{\circ} 50^{\prime} \mathrm{W}\right)$. Amphipods were fixed, preserved, and dissected in $95 \%$ ethanol, post-fixed in osmium tetroxide, transferred to Freon, and criticalpoint dried. Mouth-parts and foreguts were mounted on SEM stubs, and foreguts torn open. Specimens were sputter-coated with gold and viewed in a Cambridge Mk $2 \mathrm{~A}$ Steroscan SEM at either $10 \mathrm{kV}$ or $19 \mathrm{kV}$ accelerating voltage. Unlike most other sponge associates, $P$. hystrix is not an inquiline on its sponge host (Vader 1978, Thomas \& Taylor 1981), but a micropredator. The other paramphithoid reported to be an associate of invertebrates, Epimeria parasitica from echinoderms, also is considered to be a micropredator on its hosts (Vader 1978).

\footnotetext{
- According to H. M. Reiswig (in litt.) this should be Haliclona ventilabrum (Fristedt)
}

Both tissue and spicules of the host are eaten (Fig. 1: $1 \& 2$ ). The spicules are simple, diactinic megascleres of about 100 to $170 \mu \mathrm{m}$ length. Spicules are swallowed whole along with the body tissues and Paramphithoe hystrix therefore has evolved a means of safely swallowing sharp glass needles, instead of rejecting them prior to ingesting host tissue.

Modifications of the mouth-parts necessary for processing this diet are minimal. The buccal (posterior) surface of the upper lip is smooth, and has 2 pores, possibly openings of mucus glands (Fig. 1: 3 \& 4). Such pores have not been found on the upper lip of other amphipod species. The incisor processes are toothed and oblique (Fig. 1: 5 \& 6); this allows the amphipod to shear through the spongin fibers of the sponge's skeleton (Bergquist 1978). This arrangement is not a specific adaptation for feeding on sponges, being found for example in the free-living amphipod Gammarellus angulosus (own unpubl. data). The molar processes appear to be modified to handle the sponge's spicules (Fig. 1: $6 \&$ 7). The surfaces of the molars are smooth, except at the posterior edges (Fig. 1: 7), in contrast to the rough surfaces of most amphipods' molars (unpubl. own data; see also Oleröd 1974). The general construction of the amphopod mandibular apparatus varies little (e.g. Dennell 1933, McGouther 1983). This allows the spicules to slip easily over the molar surfaces, lessening the chance of breakage. Also, the molar processes are shaped so that when the mandibles close, the molars from a short, tube-like space (' $T$ ' in Fig. 1: 8). This would align the spicules parallel to the long axes of the esophagus. A possible mucus secretion from the gland-ducts on the upper lip would coat the spicules, and aligned and coated spicules could then be swallowed without injury.

Connes (1967) reported that the sponge Tethya lyncurium forms galls in response to the amphipod 

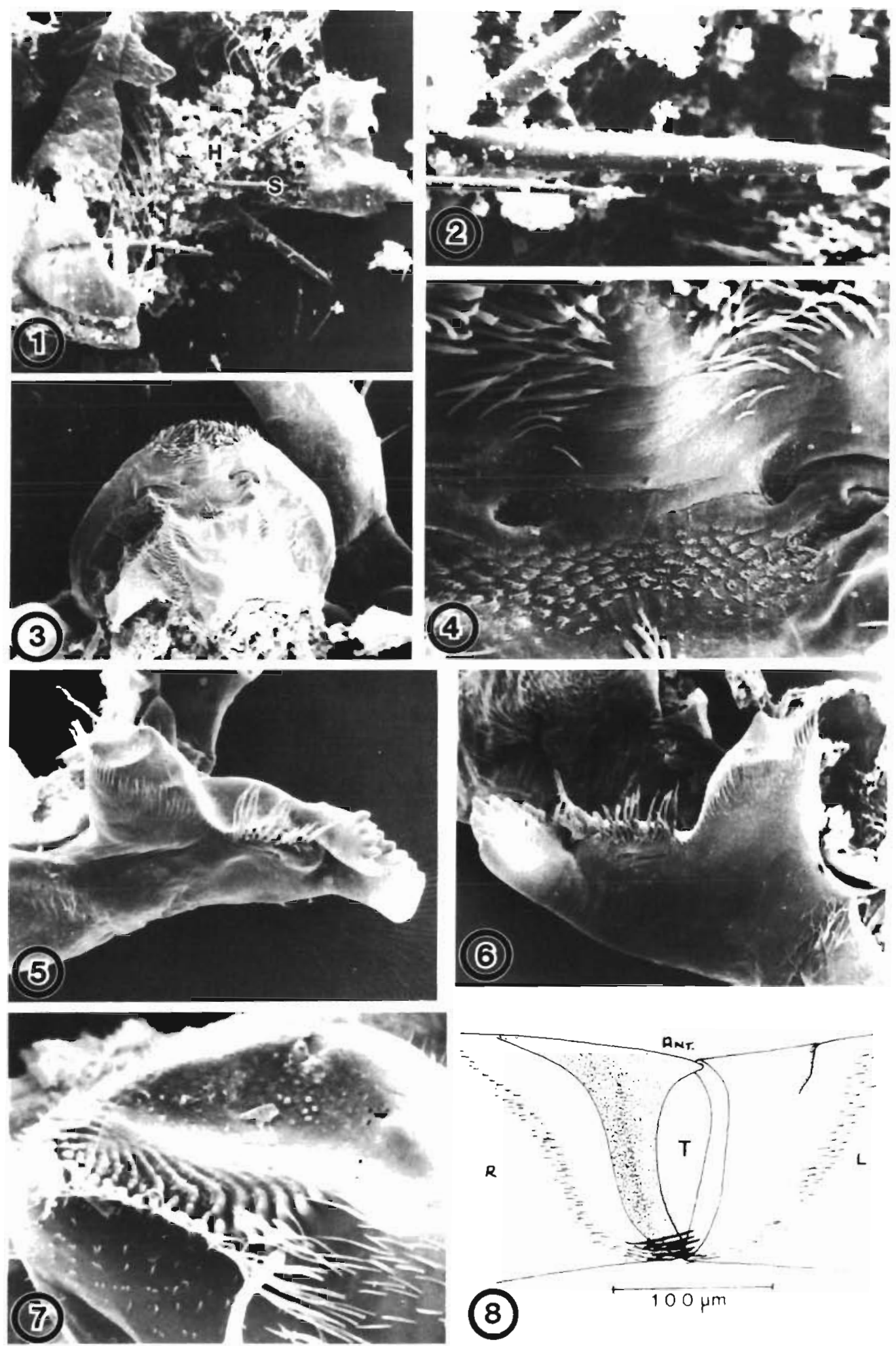

Fig. 1. Paramphithoe hystrix. (1) Foregut torn open to reveal gut contents; S: spicules; H: Host tissue; (185 $\times$ ). (2) View of spicules found in gut; $(980 \times)$. (3) Buccal (posterior) surface of upper lip; $(100 \times)$. (4) Pores on buccal surface of upper lip; (550 $\times$ ). (5) Oblique posterior view of left mandible $(100 \times)$. (6) Oblique posterior view of right mandible; (110x). (7) Surface of right mandibular molar; $(460 \times)$. (8) View of molars in situ, looking towards mouth; $T$ : tube-like space used to align spicules 
Leucothoe spinicarpa. No such response was observed in the Haliclona ventilabrum from which Paramphithoe hystrix were collected.

Acknowledgements. Paramphithoe hystrix were collected by D. Goulet. J. Kingston provided the identification of the sponge, which was made by Dr. Reiswig at the Redpath Museum, McGill University. Dr. W. Vader offered helpful comment on the manuscript. This work was supported by a NSERC grant to D. H. Steele.

\section{LITERATURE CITED}

Arndt, W. (1933), Die biologischen Beziehungen zwischen Schwämmen und Krebsen. Mitt. zool. Mus. Berl. 19: 221-325

Bergquist, P. R. (1978). Sponges. University of California Press, Berkeley

Connes, R. (1967). Réactions de Défense de l'Eponge Tethya lyncurium Lamarck, vis-à-vis des Micro-organisms et de l'Amphipode Leucothoe spinicarpa Abildg. Vie Milieu 18 A (2) : $281-289$
Dennell, R. (1933). The habits and feeding mechanism of the amphipod Haustorius areuarivs Slabber. Linn. Soc. Zool. J. 38 (259): 363-388

Fenwick, G. D., Steele, D. H. (1983). Amphipods of Placentia Bay, Newfoundland. Memorial University of Newfound land Occasional Papers in Biology. No. 7 p. 1-22

McGouther, M. A. (1983). Comparison of feeding mechanisms in two intertidal gammarideans, Hyale rupicala (Haswell) and Paracalliope australis (Haswell) (Crustacea: Amphipoda). Aust. J. mar. Freshwat. Res. 34: 717-726

Olerod, R. (1974). The mouthparts in some North Atlantic species of the genus Orchomene Boeck (Crustacea, Amphipoda). Zool. Scr. 4: 205-216

Thomas, J. D., Taylor, G. W. (1981). Mouthpart and feeding strategies of the commensual amphipod Anamixis hanseni Stebbing. Bull. mar. Sci. 31(2): 462-467

Vader, W. (1978). Associations between amphipods and echinonderms. Astarte 11: 123-134

Vader, W. (1983). Associations between amphipods (Crustacea, Amphipoda) and sea anemones (Anthozod, Actinaria). Mem. Aust. Mus. 18: 141-153

Accepted for printing on March 17, 1985 